\title{
Rhizobial isolates in active layer samples of permafrost soil of Spitsbergen, Arctic
}

\section{Denis Karlov', Anna Sazanova', Irina Kuznetsova', Nina Tikhomirova1, Zhanna Popova1, Yuriy Osledkin1, Nikita Demidov' ${ }^{2}$, Andrey Belimov ${ }^{1}$, and Vera Safronova ${ }^{1}$}

${ }^{1}$ All-Russia Research Institute for Agricultural Microbiology, Shosse Podbel'skogo, 3, Saint Petersburg, 190608, Russian Federation ${ }^{2}$ Arctic and Antarctic Research Institute,

ul. Beringa, 38, Saint Petersburg, 199397, Russian Federation

\section{Abstract}

Twenty-nine strains were isolated from two samples of the permafrost active layer of the Spitsbergen archipelago. The estimated number of bacteria ranged from $4.0 \cdot 10^{4}$ to $1.7 \cdot 10^{7} \mathrm{CFU} \cdot \mathrm{g}^{-1}$. As a result of sequencing of the $16 \mathrm{~S}$ rRNA (rrs) genes, the isolates were assigned to 13 genera belonging to the phyla Actinobacteria, Proteobacteria (classes $a, \beta$, and y), Bacteroidetes, and Firmicutes. Six isolates belonged to the rhizobial genus Mesorhizobium (order Rhizobiales). A plant nodulation assay with seedlings of legume plants Astragalus norvegicus, A. frigidus, A. subpolaris and Oxytropis sordida, originated from Khibiny (Murmansk region, Russia) and inoculated with Mesorhizobium isolates, showed the inability of these strains to form nodules on plant roots. Symbiotic (sym) genes nodC and nodD were not detected in Mesorhizobium strains either.

Keywords: legume plants, root nodule bacteria, 16S rRNA genes, permafrost soil, Spitsbergen

\section{Introduction}

Root nodule bacteria (rhizobia) belong to one of the most important groups of soil microorganisms that form nitrogen-fixing symbiosis with legumes, which allows them to enrich nitrogen-depleted soils, making it available to other plants. (Tikhonovich and Provorov, 2009).

Russia's northern territories will increasingly be used for agricultural land as a result of global climate warming. In the Russian Arctic zone, there has an expansion of the areas occupied by more productive plant communities, the so-called "greening" of the tundra. This is mainly associated with an increase in temperature, the growing season duration and the thawing depth change of permafrost soils. These processes activate soil microorganisms, which contributes to a more intensive accumulation of organic matter in the forming phytocenoses (Belonovskaya et al., 2016). As a result, free-living rhizobial bacteria can form highly adaptive legume-rhizobial symbioses, penetrating new landscapes, such as the Arctic tundra. Legumes are known to play an important role in pasture phytocenoses and are the main source of protein for herbivorous farm animals (Parakhin and Petrova, 2009; Pryadilshchikova, Kalabashkin and Konovalova, 2018).

From the permafrost soil of the Arctic, isolates were obtained related to the genera whose representatives can form nitrogen-fixing symbiosis with legumes. Strains of the genus Burkholderia were isolated from the permafrost of the Canadian Arctic (Wilhelm, Niederberger, Greer and Whyte, 2011). Isolates belonging to the genera Bradyrhizobium, Rhizobium, Devosia, and Methylobacterium, as well as the species Mesorhizobium gobiense, were obtained from the soils of northeastern Greenland (Ganzert, Bajerski and Wagner, 2014). It should be mentioned that the type strain Mesorhizobium gobiense $83330^{\mathrm{T}}$ was isolated from the nodule of Oxytro-

$$
\text { type strain Mesorhizobium gobiense } 83330 \text { was isolated from the nodule of Oxytro- }
$$

Citation: Karlov, D., Sazanova, A.,
Kuznetsova, I., Tikhomirova, N., Popo

Osledkin, Yu., Demidov, N., Belimov, A., and
Safronova, V. 2021. Rhizobial isolates in

active layer samples of permafrost soil of

Authors' information: Denis Karlov,

Junior Researcher, orcid.org/0000-0002-

Irina Kuznetsova, Engineer-Researcher,

Thesearcher, orcid.org/0000-

Senior Researcher, orcid org

Org/0000-0002-3462-7747: Andrey Belimov,

Manuscript Editor: Kirill Antonets,

Received: September 2, 2020;

Accepted: December 21, 2020

an open-access article distributed und the terms of the License Agreement with permits to the authors unrestricted

Funding: The work was performed with Russian Science Foundation support (grant No. 20-76-10042). Sampling, chemical analysis of samples and isolation of strain were supported by the Russian Science long-term storage of strains was supported by the Program for the Development and Inventory of Bioresource Collections.

The research was performed using equipment of the Core Centrum "Genomic Technologies, Proteomics and Cell Biology" in ARRIAM.

Competing interests: The authors have declared that no competing interests exist. 
pis glabra growing in the desert soils of China. This strain, in addition to the host plant, is also able to form nodules on Glycyrrhiza uralensis, Lotus corniculatus, and Robinia pseudoacacia plants, as shown by cross-nodulating tests (Han et al., 2008). Of the Late Pleistocene (20-35 thousand years ago) permafrost soil of the Kolyma lowland, a dominant phylotype was identified, which showed 99.3\% similarity to Bradyrhizobium canariense (Kudryashova et al., 2013). The ability of strains of this species to form effective symbiosis with various legumes endemic from the tribe Genisteae growing in the Canary Islands has been shown (Vinuesa et al., 2005).

Isolates belonging to Rhizobium sp. (Singh et al., 2017) and Burkholderia sp. (Hansen, Herbert, Mikkelsen and Jensen, 2007) were isolated from permafrost soil of Spitsbergen. The metagenomic studies of the active permafrost layer in this archipelago revealed DNA and RNA of symbiotic nitrogen-fixing bacteria of the genera Rhizobium and Bradyrhizobium (Schostag et al., 2015). The above works were devoted to the description and study of the bacterial biodiversity, including root nodule bacteria, in the permafrost of Spitsbergen. However, their ability to form nitrogen-fixing symbioses with plants was not studied.

Currently, native species of legume plants do not grow on Spitsbergen. The presence of a randomly introduced species of Trifolium repens L. in the area of the village of Barentsburg (https://svalbardflora.no/index. php?id=638) and Pyramid (Svenning, Røsnes, Lund and Junttila, 2001) was noted. The clover genotypes from Spitsbergen have been shown to have a higher dry matter mass as well as greater frost resistance compared to the two varieties (Norstar and AberHerald) from central Norway (Svenning, Røsnes, Lund and Junttila, 2001). The same authors selected soil samples in various areas of Spitsbergen, including in the area of the village Pyramid. Clover plants planted in this soil formed nodules and their microsymbionts were identified as Rhizobium leguminosarum bv. trifolii (Fagerli and Svenning, 2005). Clover plants grown in other soil samples of Spitsbergen did not form nodules, which suggests the introduction of rhizobia together with clover seeds. However, attempts to use other species of leguminous plants, including Arctic ones, as a selective factor for the search for root-nodule bacteria have not been described.

It is known that the genus Mesorhizobium belongs to an extensive group of rhizobia, isolated from soils and root nodules of legume plants growing around the world (Helene, Dall'Agnol, Delamuta and Hungria, 2019). Mesorhizobium strains form nitrogen-fixing symbiosis with a wide range of host plants from the genera Acacia, Alhagi, Amorpha, Biserrula, Caragana, Chamaecrista, Leucaena, Lotus, Phaseolus, Prosopis, Robinia and Sophora, including various species of Astragalus (Willems, 2014). The broad distribution of Mesorhizobium strains, allied with the ability to establish symbiotic relationships with many genera of legumes, makes it promising for use in agriculture (Helene, Dall'Agnol, Delamuta and Hungria, 2019).

Arctic rhizobia are of interest for studying the evolutionary development of nitrogen-fixing bacteria and their adaptation to low temperatures, and also make it possible to analyze the functional relations between rhizobia and leguminous plants in isolated indigenous populations of the North (Caudry-Reznicket, Prevost and Schulman, 1986). However, the biodiversity of root nodule bacteria in the Arctic territories and their symbiotic interactions with legumes are practically not studied in Russia.

The purpose of this work was to study the biodiversity of bacterial isolates in samples of the active layer of permafrost soil of Spitsbergen (including rhizobia, capable of forming a nitrogen-fixing symbiosis with legumes), as well as to study the ability of the obtained rhizobial isolates to form root nodules with Arctic legume plants.

\section{Materials and methods}

Seeds of legumes Astragalus norvegicus, A.frigidus, A. subpolaris and Oxytropis sordida were collected in Khibiny (Kola Peninsula, Russia) in 2018. The coordinates of the collection sites are from $67^{\circ} 43^{\prime} 8.7^{\prime \prime}$ to $67^{\circ} 48^{\prime} 6.9^{\prime \prime} \mathrm{N}$ and from $33^{\circ} 35^{\prime} 39.1^{\prime \prime}$ to $33^{\circ} 36^{\prime} 24.1^{\prime \prime} \mathrm{E}$.

Two samples of frozen soil were collected in 2018 by aseptic drilling of borehole 10 (56 $\mathrm{m}$ above sea level (a.s.l.), $77.99332^{\circ} \mathrm{N}, 14.66114^{\circ} \mathrm{E}$ ) on the slope of pingo Fili in Grøndalen valley in the vicinity of the Russian mine Barentsburg on West Spitsbergen (Demidov et al, 2019). Frozen conditions of cores were maintained during drilling, sampling and transportation to the laboratory. Modern mean annual air temperatures equals $-2.2^{\circ} \mathrm{C}$, permafrost temperature at zero amplitude depth amounts to $-3.56^{\circ} \mathrm{C}$ and the active layer thickness amounts to approximately $1.5 \mathrm{~m}$ in this part of West Spitsbergen.

The uppermost part of borehole 10 from 0 to $2.5 \mathrm{~m}$ below surface (b.s.) includes the modern top soil at 0 to $0.1 \mathrm{~m}$ b.s. with living shrub material and a buried soil formation at 0.25 to $0.4 \mathrm{~m}$ b.s. with decomposed similar shrub material. Both modern and buried soil were sampled and used in this study (Table 1). The minerogenic material was characterised by fine sand and loam, including gravel. The cryostructures were wavy lenticular with

\begin{tabular}{|c|c|c|}
\hline $\begin{array}{c}\text { № } \\
\text { sample }\end{array}$ & $\begin{array}{l}\text { Depth, } \\
\text { m }\end{array}$ & Cryolithological description \\
\hline 1 & $0.0-0.1$ & $\begin{array}{l}\text { Modern top soil with living shrub mate- } \\
\text { rial, fine sand and loam with wavy lenticu- } \\
\text { lar cryostructures including gravel. }\end{array}$ \\
\hline 2 & $0.3-0.39$ & $\begin{array}{l}\text { Buried soil with decomposed shrub mate- } \\
\text { rial, fine sand and loam with wavy lenticu- } \\
\text { lar cryostructures including gravel. }\end{array}$ \\
\hline
\end{tabular}


ice lenses up to $2 \mathrm{~cm}$ thick. Toward $2.5 \mathrm{~m}$ b.s. the clay content increased as the gravel content decreased. The ion content of dry residue was about $55 \mathrm{mg} / \mathrm{l}$, with predominantly $\mathrm{HCO}_{3}{ }^{-}$and $\mathrm{Ca}^{2+}$. The $\mathrm{pH}$ was neutral (6.8).

\section{Isolation of pure cultures of microorganisms}

To isolate microorganisms, we used the original and 10 -fold diluted modified yeast extract mannitol agar (YMA, Vincent, 1970) supplemented with $0.5 \%$ succinate (YMSA, Safronova et al., 2015) for the cultivation of root nodule bacteria; Tryptic Soy Broth (TSB, Sigma, USA) supplemented with $20 \mathrm{~g} / \mathrm{L}$ agar for heterotrophs; R2A agar medium (Oxoid, UK) for oligotrophs (Vishnivetskaya et al., 2000); meat peptone agar (GMF, NICF, Russia) for mesophilic microorganisms; Ashby's medium for nitrogen-fixing (oligonitrophils) microorganisms (Egorov, 1976). The cultivation was carried out at a temperature of $22^{\circ} \mathrm{C}$ for two weeks, and results were recorded starting from the second day. To determine the number of colony-forming units (CFU), $1 \mathrm{~g}$ of soil was suspended in $10 \mathrm{ml}$ of sterile water, followed by 10 -fold dilutions and plating on solid nutrient media.

All strains were deposited in the Russian Collection of Agricultural Microorganisms (RCAM, WDCM 966) and stored at $-80{ }^{\circ} \mathrm{C}$ in the automated Tube Store (Liconic Instruments, Lichtenstein) as described previously (Safronova and Tikhonovich, 2012). Information on isolates is available in the online RCAM database (http:// www.arriam.spb.ru.).

\section{Identification of the isolates and bioinformatic analysis}

Identification of the isolates was determined by amplification, purification of the PCR product, and sequencing of the 16S rRNA gene, as described previously (Safronova et al., 2015, 2019). The DNA fragment was sequenced using an ABI PRISM 3500xl genetic analyzer (Applied Biosystems, USA).

The search for homologous sequences and related type strains was performed using the NCBI GenBank database (https://www.ncbi.nlm.nih.gov) and the BLAST program (https://blast.ncbi.nlm.nih.gov/Blast.cgi). The phylogenetic tree was constructed using the MEGA7 program and the neighbour-joining method (Tamura et al., 2011). The evolutionary distances were computed using the maximum composite likelihood model.

The $r r s$ sequences were deposited to the NCBI GenBank database under accession numbers: MT912817MT912845.

\section{Sterile test-tube experiment}

Seeds of leguminous plants Astragalus norvegicus, A.frigidus, A.subpolaris and Oxytropis sordida were surface sterilized by treatment with $\mathrm{H}_{2} \mathrm{SO}_{4}$ for $5 \mathrm{~min}$. The treated seeds were rinsed carefully with sterile water and germinated on filter paper in Petri dishes at $+25^{\circ} \mathrm{C}$ in the dark for 3 days. Seedlings were transferred in $50 \mathrm{ml}$ glass tubes ( 2 seedlings per tube) containing $3 \mathrm{~g}$ of sterile vermiculite. Each glass tube was supplemented with $6 \mathrm{ml}$ of the nutrient solution $(\mathrm{g} / \mathrm{l}): \mathrm{K}_{2} \mathrm{HPO}_{4} 1.0$, $\mathrm{KH}_{2} \mathrm{PO}_{4} 0.25, \mathrm{MgSO}_{4} 1.0, \mathrm{Ca}_{3}\left(\mathrm{PO}_{4}\right)_{2} 0.2, \mathrm{FeSO}_{4}$ 0.02, $\mathrm{H}_{3} \mathrm{BO}_{3} 0.005,\left(\mathrm{NH}_{4}\right)_{2} \mathrm{MoO}_{4} 0.005, \mathrm{ZnSO}_{4} \times 7 \mathrm{H}_{2} \mathrm{O} 0.005$, $\mathrm{MnSO}_{4} 0.002$ (Novikova and Safronova, 1992). Seedlings were inoculated with Mesorhizobium isolates 1Y-1, 1Y-3, $1 \mathrm{Y}-5,1 \mathrm{Y}-8,1 \mathrm{G}-2$ and 1G-4 in the approximate amount of $10^{6}$ cells per tube as well as with two soil extracts from different horizons of the active layer of permafrost soil of borehole 10 (Spitsbergen). The uninoculated plants were used as negative control. The plant nodulation assay was carried out in duplicate. Plants were cultivated for 35 days in the growth chamber with $50 \%$ relative humidity and four levels of illumination and temperature: night (dark, $\left.18^{\circ} \mathrm{C}, 8 \mathrm{~h}\right)$, morning $\left(200 \mu \mathrm{mol} \mathrm{m}{ }^{-2} \mathrm{~s}^{-1}, 20^{\circ} \mathrm{C}, 2 \mathrm{~h}\right.$ ), day $\left(400 \mu \mathrm{mol} \mathrm{m}{ }^{-2} \mathrm{~s}^{-1}, 23{ }^{\circ} \mathrm{C}, 12 \mathrm{~h}\right)$, evening $(200 \mu \mathrm{mol}$ $\left.\mathrm{m}^{-2} \mathrm{~s}^{-1}, 20^{\circ} \mathrm{C}, 2 \mathrm{~h}\right)$. Illumination was performed by $\mathrm{L}$ 36W/77 FLUORA lamps (Osram, Germany).

\section{Amplification of nodC and nodD genes in rhizobial isolates}

To reveal the potential ability of Mesorhizobium isolates to nodulate, the symbiotic nodC and nodD genes were amplified. For nodC genes, primers were used: nodCF (5'- AYGTHGTYGAYGACGGTTC - 3') / nodCI (5'CGYGACAGCCANTCKCTATTG - 3') (Laguerre et al., 2001) and the PCR protocol as described earlier (Wei, Young and Bontemps, 2009). For nodD genes, primers were used: (5'- GCGAACGYWTTCTGACACC- 3') / (5'- TCSGTAAATSCSGGAAG - 3') and the PCR protocol as described earlier (Ji et al., 2015). The strains $M e$ sorhizobium japonicum Opo-235 and Opo-242, as well as the strain M. kowhaii Ach-343 (Safronova et al., 2018; 2019) were used as reference strains.

\section{Multi-substrate testing}

The enzymatic activities of the isolates were studied using the GENIII MicroPlate microassay system (BioLog, USA), which analyzes the ability of bacteria to metabolize 71 carbon sources and resistance to 23 chemicals. For the test analysis, isolates belonging to the bacterial genera presented in the GEN III database were selected. The analysis was performed according to the manufacturer's recommendations, with the exception of the extended incubation period for strains 2G-2 and 2R-3 (2 days). 


\section{Results and discussion}

\section{Isolation of pure cultures of microorganisms}

The number of microorganisms varied within $1.4 \cdot 10^{6}-$ $1.7 \cdot 10^{7} \mathrm{CFU} \cdot \mathrm{g}^{-1}$ (sample 1 ) and $4.0 \cdot 10^{4}-1.1 \cdot 10^{5} \mathrm{CFU} \cdot \mathrm{g}^{-1}$ (sample 2) depending on the medium and the dilution rate. The data obtained are comparable with the results of previous studies on the number of microorganisms in the active layer of the permafrost soil of Spitsbergen (Singh et al., 2017; Trubitsyn et al., 2019). For sample 1, the maximum number of CFU/g was detected on YMSA, 1/10 R2A and 1/10 TSA; for sample 2 - on YMSA medium.

Due to the use of various nutrient media, it was possible to expand the range of isolated bacteria. Representatives of four bacterial taxa (Streptomyces fildesensis, Arthrobacter humicola, Mesorhizobium sp. and Pseudomonas sp.) were isolated on two or more media. The other strains were isolated on one medium: on
YMSA - representatives of the genera Rhodococcus, Kocuria, Citricoccus, Sphingomonas, Mucilaginibacter and Planococcus; on R2A - Streptomyces, Streptacidiphilus and Arthrobacter; on GMF - Arthrobacter; on TSA Luteibacter; on Ashby - Caballeronia.

\section{Phylogenetic analysis}

A total of 29 bacterial isolates were obtained, grouped into 13 genera and 16 species (Table 2). Sequence analysis of the rrs gene of the obtained isolates showed that they belong to the following bacterial phyla: Actinobacteria, Proteobacteria (classes $\alpha, \beta$ and $\gamma$ ), Bacteroidetes and Firmicutes. The most numerous (both in the number of isolated strains and in the number of genera) was the phylum Actinobacteria, represented by the genera Arthrobacter (6 strains), Streptomyces (5 strains), as well as Streptacidiphilus, Rhodococcus, Kocuria, and Citricoccus (1 strain each). The phylum Proteobacteria was represented by the genera Mesorhizobium and

Table 2. The similarity between the isolates obtained in the work and the closest type strains based on the 16S rRNA gene sequencing

\begin{tabular}{|c|c|c|c|c|c|}
\hline $\begin{array}{l}\text { Isolate } \\
\text { number* }\end{array}$ & Closest type strain & Isolation source & $\underset{\%}{\text { Similarity, }}$ & Phylogenetic group & $\begin{array}{c}\text { Accession } \\
\text { number }\end{array}$ \\
\hline $\begin{array}{l}\text { 1R-6, 1G-1, } \\
1 \mathrm{~A}-1,1 \mathrm{~T}-1\end{array}$ & Streptomyces fildesensis GW25- ${ }^{5} \mathrm{~T}$ & Soil of Antarctica & $\begin{array}{l}99.36- \\
99.63\end{array}$ & \multirow{9}{*}{ Actinobacteria } & DQ408297 \\
\hline $1 Y-4$ & Rhodococcus qingshengii JCM $15477^{\top}$ & Carbendazim-contaminated soil & 99.36 & & DQ090961 \\
\hline $1 \mathrm{R}-3$ & Streptomyces paucisporeus $1413^{\top}$ & Forest soil & 98.10 & & AY876943 \\
\hline $1 \mathrm{R}-4$ & Streptacidiphilus durhamensis FSCA6 ${ }^{7} \mathrm{~T}$ & Forest soil & 98.13 & & NR_125637 \\
\hline $\begin{array}{l}2 \mathrm{~A}-2,2 \mathrm{G}-1 \\
2 \mathrm{R}-2,2 \mathrm{Y}-4\end{array}$ & Arthrobacter humicola $\mathrm{KV}-653^{\top}$ & Soil & $99.93-100$ & & AB279890 \\
\hline $2 G-2$ & Arthrobacter humicola $\mathrm{KV}-653^{\top}$ & Soil & 98.27 & & AB279890 \\
\hline $2 \mathrm{R}-3$ & Arthrobacter oryzae $\mathrm{KV}-651^{\top}$ & Soil & 98.56 & & AB279889 \\
\hline $2 Y-1$ & Kocuria rosea DSM $20447^{\top}$ & Soil & 100 & & X87756 \\
\hline $2 Y-2$ & $\begin{array}{l}\text { Citricoccus nitrophenolicus PNP1 }{ }^{\top} \\
\text { Citricoccus alkalitolerans YIM } 7001^{0} \mathrm{~T}\end{array}$ & $\begin{array}{l}\text { Sludge from a wastewater treat- } \\
\text { ment plant } \\
\text { Desert soil }\end{array}$ & $\begin{array}{l}100 \\
100\end{array}$ & & $\begin{array}{l}\text { GU797177 } \\
\text { AY376164 }\end{array}$ \\
\hline $\begin{array}{l}1 \mathrm{Y}-1,1 \mathrm{Y}-3 \\
1 \mathrm{Y}-5,1 \mathrm{Y}-8 \\
1 \mathrm{G}-2,1 \mathrm{G}-4\end{array}$ & $\begin{array}{l}\text { Mesorhizobium sp. CCANP61 } \\
\text { Mesorhizobium qingshengii CCBAU } 33460^{\top} \\
\text { Mesorhizobium shangrilense CCBAU } 6532^{7} \mathrm{~T}\end{array}$ & $\begin{array}{l}\text { Nodules Cicer canariense } \\
\text { Nodules Astragalus sinicus } \\
\text { Nodules Caragana bicolor }\end{array}$ & $\begin{array}{l}100 \\
99.92 \\
99.85\end{array}$ & \multirow[t]{2}{*}{ Alphaproteobacteria } & $\begin{array}{l}\text { HF931055 } \\
\text { NR_109565 } \\
\text { NR_116163 }\end{array}$ \\
\hline $1 Y-7$ & Sphingomonas panacis DCY99 ${ }^{\top}$ & Rhizosphere Panax ginseng & 99.05 & & NR_146850 \\
\hline $\begin{array}{l}1 \mathrm{~A}-2 \\
1 \mathrm{~A}-4\end{array}$ & $\begin{array}{l}\text { Caballeronia udeis } \mathrm{Hg}^{\top} \\
\text { Caballeronia sordidicola S5-B }\end{array}$ & $\begin{array}{l}\mathrm{PAH}^{* *} \text { - contaminated soil } \\
\text { fungus Phanerochaete sordida }\end{array}$ & $\begin{array}{l}98.81 \\
98.60\end{array}$ & Beta proteobacteria & $\begin{array}{l}\text { NR_125500 } \\
\text { NR_104563 }\end{array}$ \\
\hline $1 \mathrm{~T}-2$ & Luteibacter anthropi CCUG $2503^{6} \mathrm{~T}$ & Human blood & 99.28 & \multirow[b]{2}{*}{ Gammaproteobacteria } & NR_116911 \\
\hline $\begin{array}{l}2 \mathrm{~A}-1 \\
2 \mathrm{R}-1\end{array}$ & Pseudomonas frederiksbergensis JAJ28 ${ }^{\top}$ & Soil & 99.02 & & AJ249382 \\
\hline $1 Y-6$ & Mucilaginibacter dorajii DR-f4 ${ }^{\top}$ & $\begin{array}{l}\text { Rhizosphere Platycodon grandi- } \\
\text { florus }\end{array}$ & 98.15 & Bacteroidetes & GU139697 \\
\hline $2 Y-3$ & Planomicrobium soli XN13T & Soil & 99.47 & Firmicutes & NR_134133 \\
\hline
\end{tabular}

* Strains isolated on media: R - R2A; G - GMF; A - Ashby; T - TSA; Y - YMSA

**PAH - polycyclic aromatic hydrocarbon 


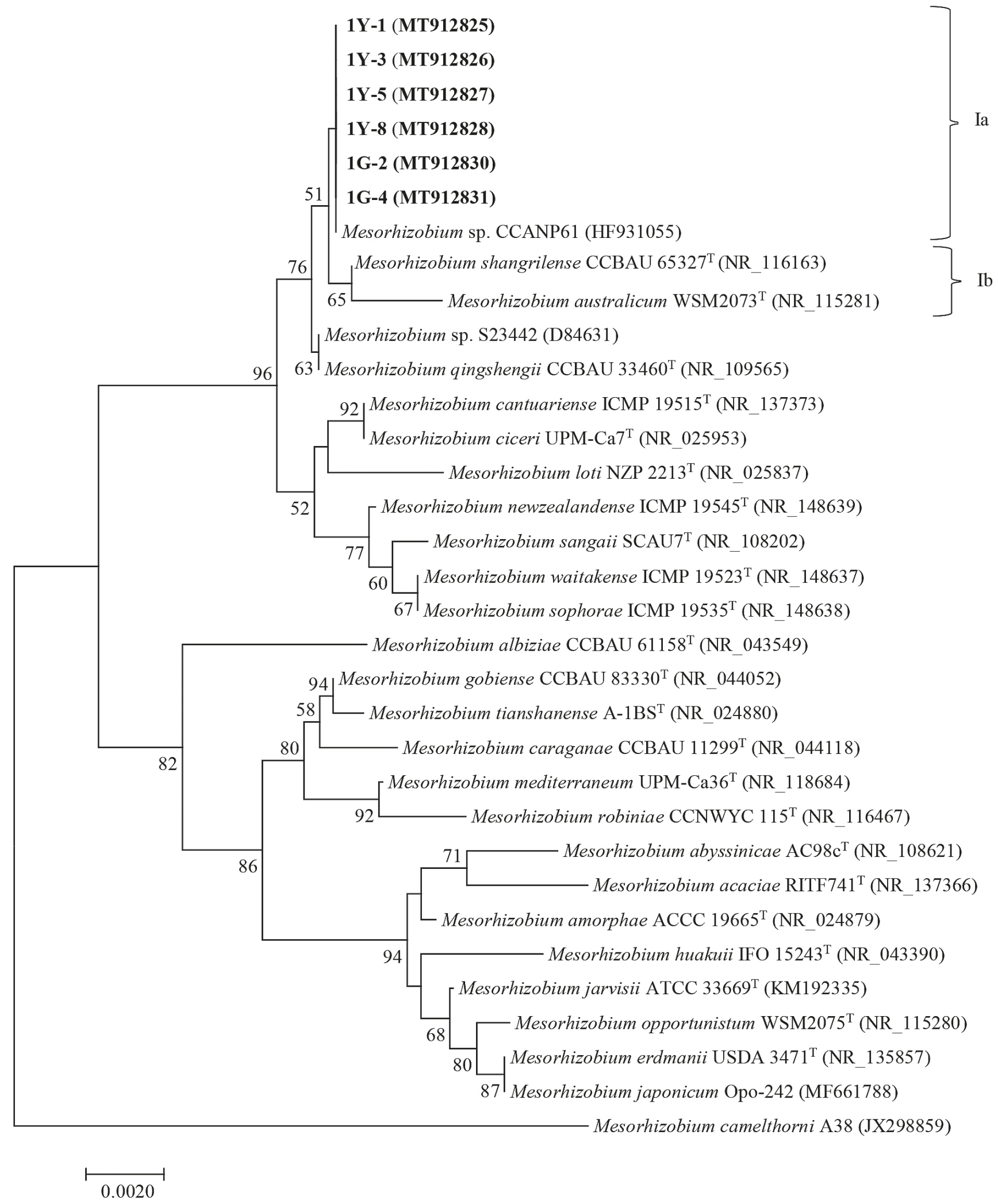

Fig. 1. Phylogenetic tree generated by the neighbour-joining method using partial $16 \mathrm{~S}$ rRNA gene sequences of the strains isolated from active layer of permafrost soil and representatives of closely related Mesorhizobium species. The isolated strains are in bold. Type strains are indicated by the letter T. Subclusters la and Ib are formed by Mesorhizobium isolates obtained in this work and representatives of closely related species. Bootstrap values of more than $50 \%$ are given. 
Table 3. Phenotypic properties of some strains obtained in the study

\begin{tabular}{|c|c|c|c|c|c|c|c|}
\hline $\begin{array}{l}\text { Phenotypic } \\
\text { property }\end{array}$ & $1 Y-4$ & $2 A-2$ & $2 G-2$ & $2 R-3$ & $2 A-1$ & $2 \mathrm{R}-1$ & $2 Y-1$ \\
\hline \multicolumn{8}{|l|}{ Growth at: } \\
\hline $\mathrm{pH} 6$ & + & + & + & + & + & + & - \\
\hline $\mathrm{pH} 5$ & - & - & - & - & - & + & - \\
\hline $1 \% \mathrm{NaCl}$ & + & + & - & + & + & + & + \\
\hline $4 \% \mathrm{NaCl}$ & - & - & - & - & - & - & - \\
\hline $8 \% \mathrm{NaCl}$ & - & - & - & - & - & - & - \\
\hline \multicolumn{8}{|l|}{ Utilization of: } \\
\hline D-Maltose & + & + & - & - & - & - & - \\
\hline D-Trehalose & + & + & - & - & - & - & - \\
\hline D-Cellobiose & + & + & - & - & - & - & - \\
\hline Sucrose & + & + & + & - & + & + & - \\
\hline D-Turanose & + & + & - & + & - & - & - \\
\hline Stachyose & + & + & + & - & - & - & - \\
\hline D-Raffinose & + & + & - & + & - & - & - \\
\hline a-D-Lactose & - & + & + & - & - & - & - \\
\hline $\begin{array}{l}\beta \text {-Methyl-D- } \\
\text { Glucoside }\end{array}$ & - & - & + & - & - & - & - \\
\hline $\begin{array}{l}\text { N-Acetyl-D- } \\
\text { Glucosamine }\end{array}$ & - & - & + & - & - & - & - \\
\hline $\begin{array}{l}\text { N-Acetyl-D- } \\
\text { Galactosamine }\end{array}$ & - & - & + & - & + & - & - \\
\hline $\begin{array}{l}\text { N-Acetyl } \\
\text { Neuraminic Acid }\end{array}$ & - & + & + & - & - & - & - \\
\hline a-D-Glucose & - & + & - & - & + & + & - \\
\hline D-Mannose & - & + & + & + & - & - & - \\
\hline D-Fructose & - & - & + & + & + & + & - \\
\hline D-Galactose & - & + & - & - & + & - & - \\
\hline 3-Methyl Glucose & + & + & - & - & - & - & - \\
\hline D-Fucose & - & + & - & + & - & - & - \\
\hline L-Fucose & - & + & + & - & - & - & - \\
\hline L-Rhamnose & - & + & - & - & - & - & - \\
\hline $\begin{array}{l}1 \% \text { Sodium } \\
\text { Lactate }\end{array}$ & + & + & - & - & + & + & - \\
\hline Fusidic Acid & - & - & - & - & - & - & - \\
\hline D-Serine & + & - & - & - & - & - & - \\
\hline D-Sorbitol & + & + & - & + & + & + & - \\
\hline D-Mannitol & - & + & - & + & + & - & - \\
\hline D-Arabitol & - & - & + & - & + & + & - \\
\hline myo-Inositol & - & + & + & - & + & + & - \\
\hline Glycerol & - & - & + & + & + & + & - \\
\hline
\end{tabular}

\begin{tabular}{|c|c|c|c|c|c|c|c|}
\hline $\begin{array}{l}\text { Phenotypic } \\
\text { property }\end{array}$ & $1 Y-4$ & $2 A-2$ & $2 G-2$ & $2 R-3$ & $2 A-1$ & $2 \mathrm{R}-1$ & $2 Y-1$ \\
\hline \multicolumn{8}{|l|}{ Utilization of: } \\
\hline $\begin{array}{l}\text { D-Fructose-6- } \\
\text { phosphate }\end{array}$ & - & + & - & - & - & - & - \\
\hline D-Aspartic Acid & + & + & - & - & + & + & - \\
\hline Glycyl-L-Proline & - & - & + & - & - & - & - \\
\hline L-Alanine & - & + & - & - & + & + & - \\
\hline L-Arginine & + & + & + & - & + & + & - \\
\hline L-Aspartic Acid & + & + & + & - & + & + & - \\
\hline L-Glutamic Acid & + & + & + & - & + & + & - \\
\hline L-Histidine & - & - & - & - & + & + & - \\
\hline $\begin{array}{l}\text { L-Pyroglutamic } \\
\text { Acid }\end{array}$ & + & - & + & - & + & + & - \\
\hline L-Serine & + & - & + & - & + & + & - \\
\hline Pectin & - & + & - & - & + & + & - \\
\hline $\begin{array}{l}\text { D-Galacturonic } \\
\text { Acid }\end{array}$ & - & + & - & - & + & + & - \\
\hline $\begin{array}{l}\text { L-Galactonic Acid } \\
\text { Lactone }\end{array}$ & - & - & - & - & + & + & - \\
\hline D-Gluconic Acid & + & + & + & + & + & + & - \\
\hline D-Glucuronic Acid & + & + & - & - & + & + & - \\
\hline Glucuronamide & + & - & - & - & + & + & - \\
\hline Mucic Acid & + & + & - & - & + & + & - \\
\hline Quinic Acid & + & - & + & - & + & + & - \\
\hline D-Saccharic Acid & + & + & - & - & + & + & - \\
\hline $\begin{array}{l}\text { p-Hydroxy- } \\
\text { Phenylacetic Acid }\end{array}$ & - & - & - & - & + & + & - \\
\hline $\begin{array}{l}\text { D-Lactic Acid } \\
\text { Methyl Ester }\end{array}$ & - & - & + & - & - & - & - \\
\hline D-Lactic Acid & - & + & + & - & + & + & - \\
\hline Citric Acid & + & + & - & - & + & + & - \\
\hline $\begin{array}{l}\text { a-Keto-Glutaric } \\
\text { Acid }\end{array}$ & - & + & + & - & + & + & - \\
\hline D-Malic Acid & - & + & - & - & + & + & - \\
\hline L-Malic Acid & + & - & + & - & + & + & - \\
\hline $\begin{array}{l}\text { Bromo-Succinic } \\
\text { Acid }\end{array}$ & - & - & + & - & - & - & - \\
\hline Tween 40 & + & + & + & + & - & - & + \\
\hline $\begin{array}{l}\text { y-Amino-Butryric } \\
\text { Acid }\end{array}$ & + & + & - & - & + & + & - \\
\hline $\begin{array}{l}\text { a-Hydroxy-Butyric } \\
\text { Acid }\end{array}$ & + & + & - & - & - & - & - \\
\hline $\begin{array}{l}\beta \text {-Hydroxy-D, } \\
\text { L-Butyric Acid }\end{array}$ & + & + & - & - & - & - & - \\
\hline
\end{tabular}




\begin{tabular}{|c|c|c|c|c|c|c|c|}
\hline $\begin{array}{l}\text { Phenotypic } \\
\text { property }\end{array}$ & $1 Y-4$ & $2 A-2$ & $2 \mathrm{G}-2$ & $2 R-3$ & $2 A-1$ & $2 \mathrm{R}-1$ & $2 Y-1$ \\
\hline \multicolumn{8}{|l|}{ Utilization of: } \\
\hline $\begin{array}{l}\text { a-Keto-Butyric } \\
\text { Acid }\end{array}$ & + & + & - & + & - & - & - \\
\hline Acetoacetic Acid & + & - & - & + & + & - & + \\
\hline Propionic Acid & + & + & - & - & + & - & + \\
\hline Acetic Acid & + & + & + & + & + & + & + \\
\hline Formic Acid & + & - & - & - & - & - & - \\
\hline \multicolumn{8}{|l|}{ Resistance to: } \\
\hline Troleandomycin & - & - & - & - & + & + & - \\
\hline Rifamycin SV & - & - & - & - & + & + & - \\
\hline Minocycline & - & - & - & - & - & - & - \\
\hline Lincomycin & - & - & - & - & + & + & - \\
\hline Guanidine $\mathrm{HCl}$ & - & - & - & - & - & - & - \\
\hline Niaproof4 & - & - & - & - & + & + & - \\
\hline Vancomycin & - & - & - & - & + & + & - \\
\hline Nalidixic Acid & + & + & + & + & - & - & + \\
\hline Aztreonam & + & + & + & - & - & - & - \\
\hline Lithium Chloride & + & - & - & - & - & - & - \\
\hline $\begin{array}{l}\text { Potassium } \\
\text { Tellurite }\end{array}$ & + & - & - & + & + & + & - \\
\hline Sodium Butyrate & + & - & - & - & - & - & + \\
\hline Tetrazollium Violet & - & - & - & - & + & + & - \\
\hline Tetrazollium Blue & - & - & - & - & + & + & - \\
\hline
\end{tabular}

Sphingomonas (6 and 1 strain, respectively) related to class $\alpha$-Proteobacteria, by the genera Caballeronia and Luteibacter (2 and 1 strain, respectively) related to class $\beta$-Proteobacteria, as well as by the genus Pseudomonas (2 strains) related to class $\gamma$-Proteobacteria. The phyla Bacteroidetes and Firmicutes were represented by the genera Mucilaginibacter and Planomicrobium, respectively (1 strain each).

From sample 1, 18 strains were isolated, while 11 strains were isolated from sample 2 (Table 2). There were no coincidences at the genus level between the isolates of both samples. In sample 1, the greatest number of strains belonged to the genera Mesorhizobium and Streptomyces (6 and 5 strains, respectively), while in sample 2 most of the strains were affiliated to the genus Arthrobacter (6 strains).

Isolates 1Y-1, 1Y-3, 1Y-5, 1Y-8, 1G-2, and 1G-4 showed $100 \%$ similarity of the rrs gene to the strain $\mathrm{Me}$ sorhizobium sp. CCANP61 (family Phyllobacteriaceae) isolated from the root nodule of the legume plant $\mathrm{C} i$ - cer canariense, an endemic to the Canary Islands (Armas-Capote et al., 2014). The closest type strains to this group were Mesorhizobium qingshengii CCBAU $33460^{\mathrm{T}}$ and Mesorhizobium shangrilense CCBAU $65327^{\mathrm{T}}$, which showed a high rate of $r$ rs-similarity to the obtained isolates (99.92 and $99.85 \%$, respectively). On the phylogenetic tree (Fig. 1) isolates 1Y-1, 1Y-3, 1Y-5, 1Y-8, 1G-2, 1G-4 and strain Mesorhizobium sp. CCANP61 formed the single subcluster Ia; Mesorhizobium shangrilense CCBAU $65327^{\mathrm{T}}$ and Mesorhizobium australicum WSM $2073^{\mathrm{T}}$ formed subcluster Ib. The levels of support of these subclusters were low (45 and $65 \%$, respectively). Both subclusters were grouped together with a $51 \%$ support level. The type strain Mesorhizobium qingshengii CCBAU $33460^{\mathrm{T}}$ previously isolated from the root nodule of the legume plant Astragalus sinicus did not form a cluster with the obtained isolates. It was shown that this strain contains the symbiotic genes nifH and nodC and effectively nodulates the host plant, which is traditionally used as a green manure in wintry fallow paddy fields (Zheng et al., 2013). The strain Mesorhizobium shangrilense CCBAU $65327^{\mathrm{T}}$ was isolated from the root nodule of Caragana bicolor growing in China. Strain CCBAU $65327^{\mathrm{T}}$ was able to nodulate a wide range of plant species of genera Caragana, Glycyrrhiza, Astragalus, Vigna and Phaseolus (Lu et al., 2009).

Isolates 2G-1, 2A-2, 2R-2, 2Y-4 showed a high level of rrs-similarity (99.93-100\%) with the type strain Arthrobacter humicola $\mathrm{KV}-653^{\mathrm{T}}$, isolated from a paddy soil sample in Saitama prefecture in Japan (Kageyama, Morisaki, Ömura and Takahashi, 2008), while the isolate 2 Y-1 was identified as Kocuria rosea (100\% rrs-similarity with the type strain DSM 20447 ${ }^{\mathrm{T}}$ ) (Stackebrandt, Koch, Gvozdiak and Schumann, 1995).

Isolate $2 \mathrm{Y}-2$ showed a $100 \%$ similarity with the type strains Citricoccus nitrophenolicus $\mathrm{PNP} 1^{\mathrm{T}}$ and Citricoccus alkalitolerans YIM $70010^{\mathrm{T}}$. The strain $\mathrm{PNP1}^{\mathrm{T}}$ was isolated from sludge from a wastewater treatment plant at a chemical factory producing pesticides in Denmark. It has been shown that this strain can utilize the xenobiotic para-nitrophenol (pNP), which is a product of human activity and a common pollutant in the environment (Nielsen, Kjeldsen and Ingvorsen, 2011). The strain Citricoccus alkalitolerans YIM $70010^{\mathrm{T}}$ was isolated from desert soil in Egypt (Li et al., 2005). The rest of the isolates showed a low level of $r r s$-similarity (98.1-99.47\%) to the closest type strains.

\section{Multi-substrate testing of isolates}

Seven isolates were tested for the ability to utilize the major classes of carbon sources and for resistance to different inhibiting chemicals (Table 3). Each strain had a unique metabolic profile. All strains grew at $1 \%(\mathrm{w} / \mathrm{v})$ 


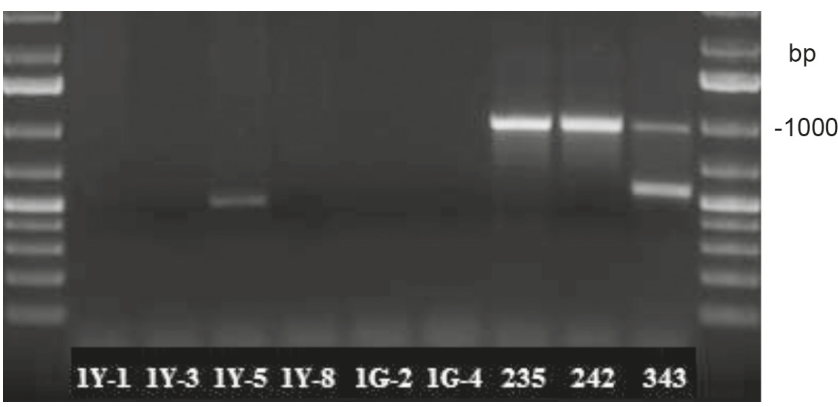

Fig. 2. Agarose gel electrophoresis of nodC PCR-products from rhizobial isolates Mesorhizobium and reference strains. 235 - M. japonicum Opo-235; 242 - M. japonicum Opo-242; 343 - M. kowhaii Ach-343

$\mathrm{NaCl}$ and $\mathrm{pH} 6$ with the exception of 2G-2 and 2Y-1. Growth at pH 5 was only in strain 2R-1. Isolate Arthrobacter sp. 2G-2 was able to utilize $\beta$-methyl-D-glucoside, $\mathrm{N}$-acetyl-D-glucosamine, glycyl-L-proline, D-lactic acid methyl ester and bromo-succinic acid; isolate of Arthrobacter sp. 2A-2 utilized L-rhamnose and D-fructose-6phosphate and isolate Rhodococcus sp. 1Y-4 utilized fusidic and formic acids.

Strains Pseudomonas sp. 2A-1 and 2R-1 had nearly identical phenotypic profiles (Table 3 ).

The common assimilated substrates for isolates $\mathrm{Ar}$ throbacter spp. 2A-2, 2G-2 and 2R-3 were D-mannose, $\mathrm{D}$-gluconic acid and acetic acid. All strains grew at $\mathrm{pH}$ 6 and in the presence of Tween 40, and also were sensitive to nalidixic acid.

Isolates Pseudomonas sp. 2A-1 and Arthrobacter humicola 2A-2 had the largest range of utilized substrates (42 and 38 substrates, respectively), isolate Kocuria rosea 2 Y-1 revealed the smallest spectrum ( 3 substrates). Isolate 2 Y-1 assimilated acetoacetic acid, propionic acid and acetic acid.

\section{Sterile test-tube experiment and the search for nod $C$ and nod $D$ genes in Mesorhizobium isolates}

To study the nodulating activity of Mesorhizobium isolates $1 \mathrm{Y}-1,1 \mathrm{Y}-3,1 \mathrm{Y}-5,1 \mathrm{Y}-8,1 \mathrm{G}-2$ and 1G-4, a sterile test-tube experiment with legume plants growing in the Murmansk region (Astragalus norvegicus, A.frigidus, A. subpolaris u Oxytropis sordida) was performed. The obtained result showed the lack of ability of isolates to form nodules on the roots of these plant species. The presence in Mesorhizobium-related isolates of symbiotic genes nodC and nodD, which belong to the common nodulation genes, was not revealed (Figs. 2 and 3).

\section{Conclusions}

In total, 29 isolates were isolated from samples of the active layer of Spitsbergen permafrost due to the use of a wide range of nutrient media. The isolates belonged to the phyla Actinobacteria, Proteobacteria (classes $\alpha, \beta$

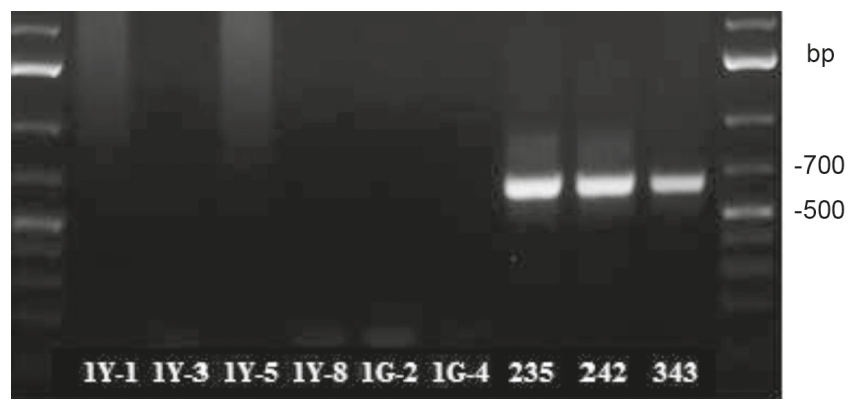

Fig. 3. Agarose gel electrophoresis of nodD PCR-products from rhizobial isolates Mesorhizobium and reference strains. 235 - M. japonicum Opo-235; 242 - M. japonicum Opo-242; $343-$ M. kowhaii Ach-343

and $\gamma$ ), Bacteroidetes and Firmicutes, and represented 13 genera and 16 species. Most of the isolated strains had a low level of rrs-similarity (less than 99.5\%) with the closest type strains, which indicates they may possibly belong to new species of microorganisms. A number of strains belong to the practically valuable groups of microorganisms that promote plant growth (genera Arthrobacter and Caballeronia) (Chung et al., 2010; Palaniappan et al., 2010) or biodegradation of xenobiotics (genus Citricoccus) (Nielsen, Kjeldsen and Ingvorsen, 2011). The multi-substrate analysis of the isolates revealed a significant variety of their phenotypic profiles. At the same time, some strains had a number of features (growth in the presence of antibiotics and heavy metal salts, acid and salt tolerance) that can be of practical use. Despite the fact that most of the isolates belong to nonsymbiotic bacteria, six isolates belonging to root nodule bacteria Mesorhizobium were isolated. To clarify the species affiliation of the Mesorhizobium isolates, additional analysis of the "housekeeping" genes is required. Although representatives of this genus are known as symbiotic microorganisms, nodulating a wide range of legumes, the isolated Mesorhizobium strains did not form nodules on the roots of the Arctic species Astragalus norvegicus, A.frigidus, A.subpolaris or Oxytropis sordida. The presence of the common nodulation genes nodC and nodD was also not detected in the obtained isolates. The negative results of the plant nodulation assay and amplification of nod-genes in these isolates could be associated with either the actual absence of these genes or their different structure. For further study of the nodulation capacity of rhizobial isolates, it is necessary to obtain their whole genome sequences and analyze symbiotic genes. The data obtained make it possible to consider the collection of strains isolated from the active layer of permafrost soil of Spitsbergen as a promising object for further research.

The selection of frost-resistant and effective strains of nodule bacteria and soil microorganisms, and analysis of the whole genomic sequences of the obtained isolates, will allow us to evaluate their agricultural potential 
for the formation of new pasture phytocenoses and for the restoration of previously disturbed lands in the Arctic regions of Russia.

\section{Acknowledgements}

The authors are grateful to L. Yu. Shipilina of the N. I. Vavilov All-Russian Institute of Plant Genetic Resources, for kindly collecting and providing seeds of legume plants originated from Murmansk region.

\section{References}

Armas-Capote, N., Pérez-Yépez, J., Martínez-Hidalgo, P., Garzón-Machado, V., del Arco-Aguilar, M., Velázquez, E., and León-Barrios, M. 2014. Core and symbiotic genes reveal nine Mesorhizobium genospecies and three symbiotic lineages among the rhizobia nodulating Cicer canariense in its natural habitat (La Palma, Canary Islands). Systematic and Applied Microbiology 37(2):140-148. https://doi. org/10.1016/j.syapm.2013.08.004

Belonovskaya, E.A., Tishkov, A.A., Vaisfel'd, M.A., Glazov, P. M., Krenke-ml., A. N., Morozova, O. V., Pokrovskaya, I. V., Tsarevskaya, N. G., and Tertitskii, G. M. 2016. "Greening" of the Russian Arctic and the modern trends of transformation of its biota. Izvestiya Rossiiskoi Akademii Nauk. Seriya Geograficheskaya 3:28-39. https:// doi.org/10.15356/0373-2444-2016-3-28-39 (In Russian)

Caudry-Reznick, S., Prevost, D., and Schulman, H. M. 1986. Some properties of arctic rhizobia. Archives of Microbiology 146(1):12-18. https://doi.org/10.1007/BF00690151

Chung, E. J., Park, J. H., Park, T. S., Ahn, J. W., and Chung, Y. R. 2010. Production of a phytotoxic compound, 3-phenylpropionic acid by a bacterial endophyte, Arthrobacter humicola YC6002 isolated from the root of Zoysia japonica. The Plant Pathology Journal 26:245-252. https://doi. org/10.5423/PPJ. 2010.26.3.245

Demidov, N., Wetterich, S., Verkulich, S., Ekaykin, A., Meyer, H., Anisimov, M., Schirrmeister, L., Demidov, V., and Hodson, A.J. 2019. Geochemical signatures of pingo ice and its origin in Grøndalen, West Spitsbergen. The Cryosphere 13:3155-3169. https://doi.org/10.5194/tc-13-3155-2019

Egorov, N.S. 1976. Workshop on Microbiology. Izdatelstvo Moskovskogo Universiteta, Moscow. 307 p. (In Russian)

Fagerli, I. L. and Svenning, M. M. 2005. Arctic and subarctic soil populations of Rhizobium leguminosarum biovar trifolii nodulating three different clover species: characterisation by diversity at chromosomal and symbiosis loci. Plant and Soil 275(1-2):371-381. https://doi. org/10.1007/s11104-005-3103-9

Ganzert, L., Bajerski, F., and Wagner, D. 2014. Bacterial community composition and diversity of five different permafrost-affected soils of Northeast Greenland. FEMS Microbiology Ecology 89(2):426-441. https://doi. org/10.1111/1574-6941.12352

Han, T. X., Han, L. L., Wu, L. J., Chen, W. F., Sui, X. H., Gu, J. G., Wang, E. T., and Chen, W.X. 2008. Mesorhizobium gobiense sp. nov. and Mesorhizobium tarimense sp. nov., isolated from wild legumes growing in desert soils of Xinjiang, China. International Journal of Systematic and Evolutionary Microbiology 58(11):2610-2618. https://doi. org/10.1099/ijs.0.2008/000125-0

Hansen, A. A., Herbert, R. A., Mikkelsen, K., and Jensen, L. L. 2007. Viability, diversity and composition of the bacterial community in a high Arctic permafrost soil from Spitsbergen, Northern Norway. Environmental Microbiology 9:28702884. https://doi.org/10.1111/j.1462-2920.2007.01403.x
Helene, L. C. F., Dall'Agnol, R. F., Delamuta, J. R. M., and Hungria, M. 2019. Mesorhizobium atlanticum sp. nov., a new nitrogen-fixing species from soils of the Brazilian Atlantic Forest biome. International Journal of Systematic and Evolutionary Microbiology 69(6):1800-1806. https://doi. org/10.1099/ijsem.0.003397

Ji, Z., Yan, H., Cui, Q., Wang, E., Chen, W., and Chen, W. 2015. Genetic divergence and gene flow among Mesorhizobium strains nodulating the shrub legume Caragana. Systematic and Applied Microbiology 38(3):176-183. https:// doi.org/10.1016/j.syapm.2015.02.007

Kageyama, A., Morisaki, K., Ōmura, S., and Takahashi, Y. 2008. Arthrobacter oryzae sp. nov. and Arthrobacter humicola sp. nov. International Journal of Systematic and Evolutionary Microbiology 58(1):53-56. https://doi.org/10.1099/ ijs.0.64875-0

Kudryashova, E. B., Chernousova, E. Y., Suzina, N.E., Ariskina, E. V., and Gilichinsky, D. A. 2013. Microbial diversity of Late Pleistocene Siberian permafrost samples. Microbiology 82(3):341-351. https://doi.org/10.1134/ S0026261713020082

Laguerre, G., Nour, S. M., Macheret, V., Sanjuan, J., Drouin, P., and Amarger, N. 2001. Classification of rhizobia based on nodC and nifH gene analysis reveals a close phylogenetic relationship among Phaseolus vulgaris symbionts. Microbiology 147(4):981-993. https://doi. org/10.1099/00221287-147-4-981

Li, W. J., Chen, H. H., Zhang, Y. Q., Kim, C. J., Park, D. J., Lee, J. C., $\mathrm{Xu}$, L.-H., and Jiang, C. L. 2005. Citricoccus alkalitolerans sp. nov., a novel actinobacterium isolated from a desert soil in Egypt. International Journal of Systematic and Evolutionary Microbiology 55(1):87-90. https://doi. org/10.1099/ijs.0.63237-0

Lu, Y. L., Chen, W. F., Wang, E. T., Han, L. L., Zhang, X.X., Chen, W.X., and Han, S.Z. 2009. Mesorhizobium shangrilense sp. nov., isolated from root nodules of Caragana species. International Journal of Systematic and Evolutionary Microbiology 59(12):3012-3018. https://doi. org/10.1099/ijs.0.007393-0

Nielsen, M. B., Kjeldsen, K. U., and Ingvorsen, K. 2011. Description of Citricoccus nitrophenolicus sp. nov., a paranitrophenol degrading actinobacterium isolated from a wastewater treatment plant and emended description of the genus Citricoccus Altenburger et al. 2002. Antonie van Leeuwenhoek 99(3):489-499. https://doi. org/10.1007/s10482-010-9513-6

Novikova, N. and Safronova, V. 1992. Transconjugants of Agrobacterium radiobacter harbouring sym genes of Rhizobium galegae can form an effective symbiosis with Medicago sativa. FEMS Microbiology Letters 93:261-268. https://doi.org/10.1111/j.1574-6968.1992.tb05107.x

Palaniappan, P., Chauhan, P. S., Saravanan, V. S., Anandham, R., and $\mathrm{Sa}, \mathrm{T}$. 2010. Isolation and characterization of plant growth promoting endophytic bacterial isolates from root nodule of Lespedeza sp. Biology and Fertility of Soils 46(8):807-816. https://doi.org/10.1007/s00374-010-0485-5

Parahin, N. V. and Petrova, S. N. 2009. Symbiotically fixed nitrogen in agroecosystems. Bulletin of Agrarian Science 18(3):41-45. (In Russian)

Pryadilshchikova, E. N., Kalabashkin, P. N., and Konovalova, S. S. 2018. Formation of pasture phytocenoses on the basis of new varieties of leguminous grasses under conditions of the European North of Russia. Vladimir Agricolist 1(83):32-35. https://doi.org/10.24411/2225-25842018-00008 (In Russian)

Safronova, V. and Tikhonovich, I. 2012. Automated cryobank of microorganisms: Unique possibilities for long-term authorized depositing of commercial mi- 
crobial strains; pp. 331-334 in Microbes in applied research: current advances and challenges. https://doi. org/10.1142/9789814405041_0066

Safronova, V.I., Kuznetsova, I. G., Sazanova, A. L., Kimeklis, A. K., Belimov, A. A., Andronov, E. E., Pinaev, A. G., Chizhevskaya, E.P., Pukhaev, A.R., Popov, K.P., Willems, A., and Tikhonovich, I. A. 2015. Bosea vaviloviae sp. nov., a new species of slow-growing rhizobia isolated from nodules of the relict species Vavilovia formosa (Stev.) Fed. Antonie van Leeuwenhoek 107(4):911-920. https://doi.org/10.1007/s10482-015-0383-9

Safronova, V. I., Belimov, A. A., Sazanova, A. L., Chirak, E. R., Verkhozina, A. V., Kuznetsova, I. G., Andronov, E. E., Puhalsky, J. V., and Tikhonovich, I. A. 2018. Taxonomically different co-microsymbionts of a relict legume, Oxytropis popoviana, have complementary sets of symbiotic genes and together increase the efficiency of plant nodulation. Molecular Plant-Microbe Interactions 31(8):833-841. https://doi.org/10.1094/MPMI-01-18-0011-R

Safronova, V., Belimov, A., Sazanova, A., Chirak, E., Kuznetsova, I., Andronov, E., Pinaev, A., Tsyganova, A., Seliverstova, E., Kitaeva, A., Tsyganov, V., and Tikhonovich, I. 2019. Two broad host range rhizobial strains isolated from relict legumes have various complementary effects on symbiotic parameters of co-inoculated plants. Frontiers in Microbiology 10:514. https://doi.org/10.3389/fmicb.2019.00514

Schostag, M., Stibal, M., Jacobsen, C. S., Bælum, J., Taş, N., Elberling, B., Jansson, J. K., Semenchuk, P., and Priemé, A. 2015. Distinct summer and winter bacterial communities in the active layer of Svalbard permafrost revealed by DNA-and RNA-based analyses. Frontiers in Microbiology 6:399. https://doi.org/10.3389/fmicb.2015.00399

Singh, P., Singh, S. M., Singh, R. N., Naik, S., Roy, U., Srivastava, A., and Bölter, M. 2017. Bacterial communities in ancient permafrost profiles of Svalbard, Arctic. Journal of Basic Microbiology 57(12):1018-1036. https://doi. org/10.1002/jobm.201700061

Stackebrandt, E., Koch, C., Gvozdiak, O., and Schumann, P. 1995. Taxonomic dissection of the genus Micrococcus: Kocuria gen. nov., Nesterenkonia gen. nov., Kytococcus gen. nov., Dermacoccus gen. nov., and Micrococcus Cohn 1872 gen. emend. International Journal of Systematic and Evolutionary Microbiology 45(4):682-692. https://doi. org/10.1099/00207713-45-4-682

Svenning, M. M., Røsnes, K., Lund, L., and Junttila, O. 2001. Vegetative growth and freezing tolerance of white clover (Trifolium repens L.) genotypes from Svalbard. Acta Agriculturae Scandinavica, Section B - Soil \& Plant Science 51(1):10-16. https://doi.org/10.1080/090647101317187843

Tamura, K., Peterson, D., Peterson, N., Stecher, G., Nei, M., and Kumar, S. 2011. MEGA5: molecular evolutionary genetics analysis using maximum likelihood, evolutionary distance, and maximum parsimony methods. Molecular Biology and Evolution 28(10):2731-2739. https://doi. org/10.1093/molbev/msr121

Tikhonovich, I. A. and Provorov, N. A. 2009. Symbioses of plants and microorganisms: molecular genetics of agrosystems of the future. St. Petersburg University Press, Saint Petersburg. 210 p. (In Russian)

Trubitsyn, V.E., Rhyzhmanova, Y. V., Zaharuk, A. G., Oshurkova, V.l., Laurinavichius, K.S., Spirina, E.V., Shcherbakova, V. A., and Rivkina, E. M. 2019. Permafrost sediments, West Spitsbergen, microbial communities, psychrophilic microorganisms, anaerobic prokaryotes. Earth 23(6):31-38. https://doi.org/10.21782/EC25419994-2019-6(31-38)

Vincent, J. M. 1970. A manual for the practical study of root nodule bacteria; pp. 73-97 in IBP Handbook. Oxford and Edinburgh: Blackwell Scientific Publications.

Vinuesa, P., León-Barrios, M., Silva, C., Willems, A., Jarabo-Lorenzo, A., Pérez-Galdona, R., Werner, D., and MartínezRomero, E. 2005. Bradyrhizobium canariense sp. nov., an acid-tolerant endosymbiont that nodulates endemic genistoid legumes (Papilionoideae: Genisteae) from the Canary Islands, along with Bradyrhizobium japonicum bv. genistearum, Bradyrhizobium genospecies alpha and Bradyrhizobium genospecies beta. International Journal of Systematic and Evolutionary Microbiology 55(2):569575. https://doi.org/10.1099/ijs.0.63292-0

Vishnivetskaya, T., Kathariou, S., McGrath, J., Gilichinsky, D., and Tiedje, J. M. 2000. Low-temperature recovery strategies for the isolation of bacteria from ancient permafrost sediments. Extremophiles 4(3):165-173. https://doi. org/10.1007/s007920070031

Wei, G., Chen, W., Young, J.P.W., and Bontemps, C. 2009. A new clade of Mesorhizobium nodulating Alhagi sparsifolia. Systematic and Applied Microbiology 32(1):8-16. https://doi.org/10.1016/j.syapm.2008.11.003

Wilhelm, R. C., Niederberger, T. D., Greer, C., and Whyte, L. G. 2011. Microbial diversity of active layer and permafrost in an acidic wetland from the Canadian High Arctic. Canadian Journal of Microbiology 57(4):303-315. https://doi. org/10.1139/w11-004

Willems, A. 2014. The family Phyllobacteriaceae; pp. 355-418 in Rosenberg, E., DeLong, E. F., Lory, S., Stackebrandt, E., Thompson, F. (Eds). The Prokaryotes: Alphaproteobacteria and Betaproteobacteria 4th edn. Springer: Berlin, Germany. https://doi.org/10.1007/978-3-642-30197-1_298

Zheng, W.T., Li Jr, Y., Wang, R., Sui, X. H., Zhang, X.X., Zhang, J. J., Wang, E. T., and Chen, W. X. 2013. Mesorhizobium qingshengii sp. nov., isolated from effective nodules of Astragalus sinicus. International Journal of Systematic and Evolutionary Microbiology 63(6):2002-2007. https:// doi.org/10.1099/ijs.0.044362-0 